\title{
Perceived Strategies Under the Focus of Strategic Positioning Theory, Resource Based-View, Strategic Mission and Organizational Typology: a Study of Companies in Southern Brazil
}

\author{
Giovani Capalonga ${ }^{\dagger}$ \\ Universidade do Vale do Rio dos Sinos - Unisinos \\ Carlos Alberto Diehl ${ }^{\Omega}$ \\ Universidade do Vale do Rio dos Sinos - Unisinos \\ Francisco Antônio Mesquita Zanini ${ }^{\mp}$ \\ Universidade do Vale do Rio dos Sinos - Unisinos
}

\begin{abstract}
This paper examines the subject of organizational strategy of companies in southern Brazil. Our aim is to propose a tool that allows the identification of strategic approaches of organizations. From theoretical viewpoint of strategic positioning, resource-based view, strategic mission and strategic typology, an integrating framework is proposed. We conducted a survey using a questionnaire with closed questions and applied it to medium and large firms in southern Brazil. Using the factorial analysis technique and cluster analysis, we analyzed the identified strategies in each cluster, comparing them with the perceived performance. The results suggest that the more strategies are aligned with the theoretical model, considering the four approaches used, the better the performance perceived by managers is.
\end{abstract}

Keywords: Strategy. Strategic positioning. Strategic typology. Resource-based view. Strategic mission.

*Author for correspondence:

\footnotetext{
. Master's in Accounting from Vale do Rio do Sinos University Address: Rua Casemiro de Abreu, Centro, Novo Hamburgo - RS Brazil

E-mail: capalonga@centroeco.com.br Telephone: (51) 3065-9710
}

${ }^{\Omega} \mathrm{Ph} . \mathrm{D}$. in Production Engineering from Santa Catarina Federal University Institution: Professor at Vale do Rio dos Sinos University

Address: Av. Unisinos, 950, Sala 5A403d-

São Leopoldo - RS - Brazil

E-mail: cd@unisinos.br

Telephone: (51 ) 35908186

\author{
${ }^{¥}$ Ph.D. in Accounting and Business \\ Organization from Universidad Autónoma \\ de Madrid \\ Institution: Assistant professor at Vale do \\ Rio dos Sinos University \\ Address: Av. Unisinos, 950. Unidade de \\ Educação Continuada, São Leopoldo - \\ RS - Brazil - E-mail: \\ fzanini@unisinos.br \\ Telephone: (51) 3590.8221
}

Note from the Editor: This article was accepted by Emerson Mainardes. 


\section{INTRODUCTION} intensity and speed of changes. In this environment, the company which has the right strategies at the right time will have a competitive advantage over the others. So to conduct proper strategic management it is necessary to know, among other practices, the strategic option adopted by the organization. The concept of strategy is one of the most researched and disseminated in research on management. Mintzberg et al. (2000), for example, characterize ten different schools (or approaches) to strategy. Similarly, various studies have been conducted on strategic cost management, for example, with different strategy characterizations. Such heterogeneity makes it difficult to compare studies. Although some studies such as Diehl (2005) have thrown some light on this subject, there is a lack of tools that help to characterize organizational strategy more clearly. Freitas \& Hoffmann (2012) state that different theoretical views imply different conclusions. Therefore, it is important to understand organizational strategy from several points of view.

Thus, the objective of this paper is to propose an instrument to identify organizational strategies. This is particularly relevant to the sphere of action of controllers, given their inclusion in the management process, specifically at the stage of strategic planning. We believe that this study contributes to a more systematic education of professionals in management control, enlarging the conceptual basis necessary for their effective participation in management of organizations.

Besides this introduction, this study includes a literature review on the issue. Then the methodological considerations are presented, followed by analysis of the along with discussion of the outcomes. In closing, we present our final considerations.

\section{LITERATURE REVIEW}

The word strategy was first used in 1688, and derives from the Greek strategia (originally meaning generalship) (WHIPP, 1996). Millennial in the military context, strategy had a connotation of management skill already at the time of Pericles (450 D. C.), when its meaning had come to express the idea of power, leadership and management (MINTZBERG; QUINN, 2001).

There are many concepts about strategies (MINTZBERG et al., 2001). Some authors adopt stricter definition lines; others see it as a broader set of elements in their way of conceptualizing strategy. The more generic and widespread of these concepts on what strategy 
is emphasize it as the path chosen by the organization to achieve its goals. Every organization seeks certain goals, and to this end must have strategies on how to achieve them. These strategies in general involve ways to use the internal resources of the organization to seize opportunities in the external environment.

For Mintzberg et al. (2001) if the planned strategy (intended strategy) does not coincide with the implemented strategy (realized strategy) by the organization, part of the intended actions were not implemented. One can classify these actions as unrealized strategy, because although included in the strategic plan, they were not implemented. On the other hand, the strategy performed by the organization can include actions not included in the plan prepared in advance. This unplanned component of strategy carried out by the company is defined as emerging strategy, which arises from learning from operations, converging on a pattern of action. Thus, the strategy effectively implemented by an organization is the sum of an intentional component, i.e., consisting of previously designed patterns that were actually implanted, with another emerging component, consisting of patterns not previously planned. The degree of combination between deliberate and emergent strategies varies among different organizations.

In the other hand, previously to the achieved strategy, there is what is called perceived strategy. It is the perception that top executives have of the strategy undertaken by the company, among them the controller. Diehl (2005) pointed out that the perceptions of the two main executives of the surveyed companies were antagonistic: while the CEO believed that the main strategy was differentiation, the CFO was seeking cost leadership. Sinickas (2006) addressed such situations in his study, which examined the problems of communication strategy. This faulty communication makes the perception of real strategy of companies different from that perceived by their executives, with all the negative consequences resulting from it.

\subsection{CONTENT OF STRATEGY}

Strategy involves a limited number of general alternative decisions about what to do in terms of investment in relation to a particular group of business units. Traditionally, these decisions have been based on the concept of portfolio management, and are only related to the resource allocation to expand, acquire or exit a particular business (CERTO; PETER, 1993; OLIVEIRA; GOMES; NEUMANN, 2003). New approaches to strategy have emerged and can easily be observed. Mintzberg et al. (2000) classified the various thoughts on strategy into 
ten schools. Of these, four approaches can be highlighted: strategic positioning, resourcebased view (RBV), strategic mission and strategic typology. They are presented below.

According to Porter (2004), once the forces that affect competition in a segment as well as their underlying causes are diagnosed, the company is able to identify its strengths and weaknesses in relation to this segment. From a strategic standpoint, the first condition is the strategic positioning of the company in relation to the underlying causes of each competitive force. According to Porter (1989), there are three ways that a company creates a defensible position in the long run, stand out against competitors and gain advantage in a sector, the well-known generic strategies. They are: to differentiate their products to enable charging a higher price, implying offering a unique value to customers, based on superior technologies (differentiation); to have a lower cost to gain greater market share (cost leadership); or to focus on a specific segment from one of the above approaches (focus). In cost leadership, the company's focus is aimed at producing at the lowest cost in its sector. This advantage is achieved by adopting a set of functional policies to attain this goal, as well as the development of economic and technological activities at a lower cost than competitors adopt. The second generic strategy, differentiation, consists of creating products or services that are unique within the scope of the entire industry. For this, the company must develop activities with high quality in such a way to offer differentiated benefits that make its product more attractive to buyers than that of its competitors. The last generic strategy, focus, seeks to concentrate on a particular buyer group, a segment or a line of products or a geographic market. This strategy defines the service capacity of the company for a particular target, and therefore its functional policies are directed to achieve the end. The strategy of focus is directed to serve its strategic target better than competitors, who act more widely.

For Sehnem, Lazzarotti \& Bandeira-de-Mello (2010), the Porter paradigm is the dominant one in Brazil, although there a decline in its use and most studies are superficial. However, the Porter paradigm has only an instrumental approach, without considering broader objectives (RODRIGUES FILHO, 2004). Furthermore, some studies point out that it is possible to combine generic strategies (ACQUAAH; YASAI-ARDEKANI, 2008) when well done, partially countering Porter.

Although widely discussed in recent decades, the RBV is not a new theoretical model. Its main proponents advocate its genesis in the work of the economic theory of David Ricardo, Joseph Schumpeter and Edith Penrose (BARNEY, 1991; GRANT, 1992). The literature on competitive strategy emphasizes strategic positioning in terms of choice between 
cost and differentiation and between broad and narrow markets (PORTER, 2004). Consideration of organizational resources is seen as a fundamental premise in these choices. Thus, it is the organization's position, based on its resources, that allows it to pursue a particular strategic positioning in an industry (GRANT, 1992). Studies like Newbert (2008) have reinforced empirically the view of resources as determinants of performance.

According to the RBV model, organizations seek to acquire or develop resources (and capabilities) that are valuable and difficult to imitate. The underlying premise of the RBV regarding competitive advantage is that the organizations' resources are heterogeneous and non-transferable. When strategic resources are evenly distributed by various organizations and are characterized by being mobile (i.e., easy to acquire), it is not generally expected that sustainable competitive advantage can be achieved from their use. However, not all resources have the potential to contribute to a sustainable competitive advantage. To have this potential strategic impact, a resource must have four attributes: (a) be valuable (to exploit opportunities and/or neutralize external threats), (b) be rare among current and potential competitors, (c) be imperfectly imitable and (d) have no valuable strategic substitutes that are not rare or imitable.

The RBV model retains an important role in strategy research despite critiques. For instance, Pacheco-de-Almeida \& Zemsky (2007) mentioned a tautological link among valuable, rare, and inimitable resources and superior performance and lack of deepness in specificity in defining those concepts. In fact, RBV has ignored the influence of capability weaknesses in competition, focusing only in strengths (SIRMON et al., 2010). Lamberg et al. (2009) advocated a similar idea.

In strategic mission, the extent and nature of the dependency of a unit with other units within the same organization are some of the most critical strategic issues in terms of strategies of business units (GUPTA; GOVINDARAJAN, 1984). The strategic mission (or portfolio strategy) involves a feature desired by an organizational unit that emerges from the choice between growth in market share and maximization of cash flow in the short term (HENDERSON, 1979). Some measurement models of this choice have been proposes for this task. The BCG matrix, for example, is based on the rate of industry growth and relative share of the enterprise market. These two dimensions indicate the competitive position of a unit of an organization in its sector and the potential to generate cash flow necessary to operate such a unit (HOFER; SCHENDEL, 1978; HENDERSON, 1979).

The competitive position of a unit is a combination of those measures, which will result in a "strategic policy" (PORTER, 2004, p. 379), where the unit must build, hold or harvest, 
according to its position within that matrix. For this author and also for Gupta \& Govindarajan (1984), on one side of the matrix is Build - whose mission is to increase market share and competitive position. Although it focuses on winning in the short term, the cash flow can be low or negative. It is likely that this unit has "weak competitive positions" in "relatively attractive industries" (GUPTA; GOVINDARAJAN, 1984). On the other side is Harvest - in which the mission is to prefer short-term gain and cash flow, although this can result in loss of the market share and competitive position. It is likely that this unit has "strong competitive positions" in "relatively unattractive industries." In the middle is Hold - which has as characteristic the maintenance of market share, where quality improvements and marketing campaigns are crucial to success. Such units, generally have a high relative share in the market and are in mature industries (GUPTA; GOVINDARAJAN, 1984). In SMEs, strategic mission is the most appropriate approach to understand strategic deployment, through processes analysis (ATES, 2008).

As for the strategic typology, the vision of Miles \& Snow (1978) is based on the approach that varies according to the dynamics of the organizational process (the adaptive cycle), attributed to the perception that the ruling coalition has of the external environment. In the vision of these authors the strategies are:

Defender - it is concerned with stability, i.e., to "isolate a portion of the market to create a stable domain [...] a limited set of products is directed to a narrow segment of the potential market" (Miles et al., 1978, p. 550). Within this limited field, the defender aggressively tries to prevent competitors from entering its 'ground'. Such behaviors include economic actions to compete by price or high quality products. Nevertheless, defenders tend to ignore developments and trends outside their fields.

Prospector - it is responsible for its environmental choices in a way that is almost the opposite of the defender. Generically, the prospector establishes an environment that is more dynamic than other types of organizations within the same industry. The main competency is to find and exploit new products and market opportunities. Maintaining reputation for the pursuit of product innovation and market development can be as important as profitability. This may make it difficult to achieve profitability levels equal to the most efficient defender (MILES et al., 1978).

Analyst - "based on own research, the Defender and Prospector seem to stand in final opposition of a continuous adjustment of the strategy" (MILES et al., 1978). Between these two extremes, in a combination of the two typologies, the Analyst is the only combination 
that represents a viable alternative among these other strategies. Indeed, the analyst is an organization that seeks to minimize risk while maximizing profit opportunities. It seeks to combine the strengths between the Prospector and the Defender within a simple system. This strategy is difficult to practice, especially in industries characterized by quick market and technological changes. For Miles et al. (1978), the word that best describes it is "Balance."

\begin{tabular}{|c|c|c|c|}
\hline Study & Variable & Standards & Features \\
\hline \multirow{4}{*}{$\begin{array}{l}\text { Miles \& } \\
\text { Snow } \\
(1978)\end{array}$} & \multirow{4}{*}{$\begin{array}{l}\text { Strategic } \\
\text { Typology }\end{array}$} & Defender & $\begin{array}{l}\text { Domain stable, limited product range, competes for low cost or high } \\
\text { quality, superior efficiency, centralized structure. }\end{array}$ \\
\hline & & Prospector & $\begin{array}{l}\text { Turbulent field, new products seeking market opportunities, uncertain } \\
\text { environment, flexible structure. }\end{array}$ \\
\hline & & Analyst & $\begin{array}{l}\text { Hybrid, traditional products, enter new markets after viable, matrix } \\
\text { structure. }\end{array}$ \\
\hline & & Reactor & $\begin{array}{l}\text { Lacks a coherent strategy, structure unfit to the purpose, lost } \\
\text { opportunities, unsuccessful. }\end{array}$ \\
\hline \multirow{3}{*}{$\begin{array}{l}\text { Porter } \\
(1989)\end{array}$} & \multirow{3}{*}{$\begin{array}{l}\text { Position- } \\
\text { ing } \\
\text { strategies }\end{array}$} & Differentiation & $\begin{array}{l}\text { Leadership in "only" products leads to higher prices, emphasis on } \\
\text { marketing and research. }\end{array}$ \\
\hline & & Leadership Costs & $\begin{array}{l}\text { Low price, focus on high market share, unified products, economies of } \\
\text { scale. }\end{array}$ \\
\hline & & Focus & Focus on defined group of buyers, product line or geographic market. \\
\hline \multirow{3}{*}{$\begin{array}{l}\text { Hofer \& } \\
\text { Schendel } \\
\text { (1978); } \\
\text { Gupta \& } \\
\text { Govin- } \\
\text { darajan } \\
(1984)\end{array}$} & \multirow{3}{*}{$\begin{array}{l}\text { Strategic } \\
\text { Mission }\end{array}$} & Build & $\begin{array}{l}\text { Increase market share, investment capacity, low relative market share, } \\
\text { high growth of industry. }\end{array}$ \\
\hline & & Hold & $\begin{array}{l}\text { Maintaining its market share, quality improvements and marketing } \\
\text { campaigns are crucial to success; high relative share of the market and } \\
\text { mature industries. }\end{array}$ \\
\hline & & Harvest & $\begin{array}{l}\text { Maximize short-term gain, investment decreases rapidly; high relative } \\
\text { share of the market, declining industries. }\end{array}$ \\
\hline \multirow{3}{*}{$\begin{array}{l}\text { Barney } \\
(1991) ; \\
\text { Grant } \\
(1992, \\
1991)\end{array}$} & \multirow{3}{*}{$\begin{array}{l}\text { Resource } \\
\text { Based } \\
\text { View }\end{array}$} & Physical Capital & $\begin{array}{l}\text { Include technology, facilities and equipment in an organization, its } \\
\text { geographic location and access to raw materials; }\end{array}$ \\
\hline & & Human Capital & $\begin{array}{l}\text { Include training, experience, intelligence, relationships and individual } \\
\text { visions of the employees of an organization. }\end{array}$ \\
\hline & & $\begin{array}{l}\text { Organizational } \\
\text { Capital }\end{array}$ & $\begin{array}{l}\text { Include the formal structure of the organization, its systems of planning, } \\
\text { control and coordination as well as informal relations among its } \\
\text { different groups and between it and its environment }\end{array}$ \\
\hline
\end{tabular}

Table 1 - Classification of the Strategic Approaches

Source: Adapted from Kald, Nilsson \& Rapp (2000)

Reactive - Displays a pattern of adjustment to its environment that is inconsistent and unstable. It lacks a set of response mechanisms that can be consciously put into effect when facing environmental change. As a consequence, Reactive firms are almost in a perpetual state of instability, with uncertain and inappropriate responses, resulting in poor performance from unwillingness to act aggressively in the future, thus characterizing a residual strategy (Miles et al., 1978). The framework of Miles \& Snow framework (1978) has extensive use in the literature and seems more appropriate to identify practiced strategy. Moreover, this typology shows accordance with theory (RIGGONI; HOPPEN, 2011). For instance, Bagnoli \& Vedovato (2012) used strategic typology to investigate knowledge management coherence to strategy in SMEs (small and medium enterprises). They found that knowledge management 
and strategy configuration coherence have a positive impact on innovation performance, although not on organizational performance.

Table 1 shows the referred approaches and their main characteristics. However, Diehl (2005, p. 13) reports that "there is a certain lack of models which allows identifying the strategy and, jointly, to consolidate the different views on the subject." It is on this issue that we will focus from now on.

\subsection{STRATEGIC INTEGRATION}

Langfield-Smith (1997) proposed the integration of categories of strategies. For the author, the strategies followed by individual business units can be described by three approaches among those already described: positioning, typology and strategic mission.

To help integrate these approaches, the differences and similarities among the various classifications of the strategy should be considered. One can see these differences as related to space and focus. The typology of the prospector against the defender has a wide space, while the competitor's positioning of leadership in cost against differentiation is much narrower. The prospector against the defender classification is focused on the extent of product innovation, while the build against harvest is based on the part of the market against the tradeoff in short-term profit. Gunther (2012, p. III) also utilized the Langfield-Smith framework to "investigate interaction amongst the information attributes of strategic performance measurement systems (SPMS), the board control role and the organisation's strategy." He found a significant relationship among organizational strategy, board strategic control role and information attributes in SPMS with higher EBIT.

In Brazil, Freitas \& Hoffman (2012) also utilized an integration of two different classifications: Ansoff (1977) and Porter (1986). The authors researched small companies in southern Brazil. According to them, these classifications are the most appropriate to their study, because they are more adequate to organizations' characteristics. Ito (2011), in a theoretical essay, explores integration of Porter's value chain and RBV capacities to explain competitive advantage.

In the wake of the work of Langfield-Smith (1997), Kald, Nilsson \& Rapp (2000) systematized this approach in a more elaborate way, seeking to establish the links of each item of the three approaches presented. However, the study of Cinquini \& Tenucci (2010) did not fully support the Langfield-Smith framework. They only found consistency between 
defender/cost and leader/harvest strategy, although they pointed out the need for more research.

Despite the contributions of Langfield-Smith and Kald, Nilsson \& Rapp, the incorporation of the resource-based view is essential for the evaluation of the strategies applied by companies. The characteristics of what and how resources are used is extremely valuable for understanding these strategies. Furthermore, there are few empirical studies of RBV (PRZYCZYNSKI; BITENCOURT, 2012). Figure 1 also shows the incorporation of this last approach in the model of Kald, Nilsson \& Rap (2000).

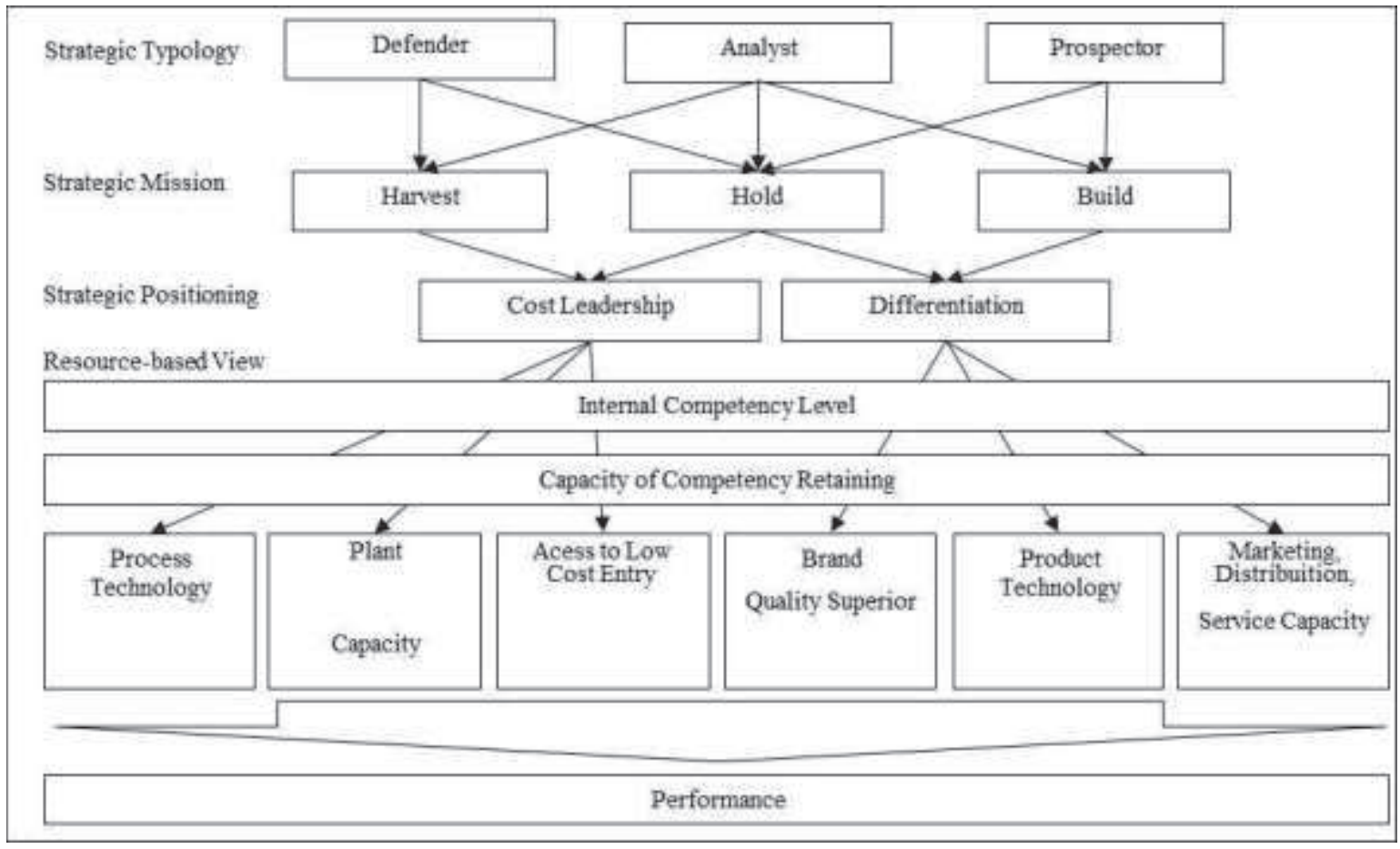

Figure 1 - Strategic Approaches

Source: Adapted from Kald, Nilsson \& Rap (2000)

For Borinelli (2006), it is necessary to incorporate the area of management control in a strategic vision. Therefore, recognizing the strategic options of the organization is fundamental for the controller to establish what information needs to be monitored and what activities need to be developed to obtain feedback on performance and to act in case of need. In fact, our study uses a perception of performance, in a broader approach to its measurement, in accordance with Canhada \& Bulgacov (2011), who suggested performance can be measured by different indicators. Therefore, we chose to ask what the managers' performance perceptions are. 


\section{METHODOLOGICAL PROCEDURES}

This study, in line with the framework of Vieira (2002), can be classified according to its nature as applied; according to its approach to the problem as quantitative, in relation to its aims as descriptive, and according to the technical procedures as a survey. This study adopts a strategy-as-practice approach similar to that proposed by Jarzabkowski \& Whittington (2008) Also Valadão \& Silva (2012) stated that strategy is what people do. Our questions use this approach. Furthermore, this study follows the recommendations of Albino et al. (2010) and adopts intended actions and social practices as investigation questions. However, some of those authors' suggestions cannot be adopted in a survey approach, as they themselves pointed out.

The sample was obtained from a database of SEBRAE ${ }^{1}$, from which we extracted the list of companies of the state of Rio Grande do Sul with 100 or more employees (medium and large by the criterion of SEBRAE), a total of 535 firms that were potential participants in the study and to which we sent invitations by e-mail. After e-mail confirmation, we sent 266 questionnaires to potential respondents and 32 of them returned the forms completed. All the collected questionnaires were examined to discount double responses. The survey instrument was developed from previous studies shown in table 2 , and it contained 91 questions $^{2}$.

\begin{tabular}{|l|l|}
\hline Author (year published) & Subject Search \\
\hline Zhuang (2000) & The RBV in electronic commerce \\
\hline Namusonge (2003) & Linking between expertise and strategy \\
\hline Kearns (1997) & Alignment of strategic information systems \\
\hline Jugdev (2003) & Management of strategic activities \\
\hline Mcdermott (2003) & Essential skills and performance of the company \\
\hline Soekarsono (2001) & Integrating strategy and economics \\
\hline Wan (2004) & Competitive forces, the level of the business and performance \\
\hline Metts (2004) & Relationship between strategic construction and performance \\
\hline Diehl (2005) & $\begin{array}{l}\text { The strategic management of cost management from the approaches of } \\
\text { strategic positioning, mission, typology and RBV }\end{array}$ \\
\hline Gupta \& Govindarajan (1984) & Strategy, managerial characteristics and effectiveness \\
\hline Gimenez et al. (1999) & Identifying the typology of strategy \\
\hline
\end{tabular}

Table 2 - Studies which have investigated the strategy in some of the proposed dimensions

The survey instrument was evaluated by three judges, one an academic with a doctorate in the area and two professionals working for companies with operations similar to those of potential respondents. The evaluations obtained were then analyzed by calculating the coefficient of content validity (CCV) following the criteria of Hernandez-Nieto (2002). The ideal CCV for matters relating to the clarity of language and the practical relevance should be higher than 0.8 (HERNANDEZ-NIETO, 2002). The items related to clarity of language whose $\mathrm{CCV}$ was lower than 0.8 were changed, as recommended by the judges, to improve understanding. As for the practical relevance, considering that the respondents did not have 
the same training, we chose to consider the items that presented ratios higher than 0.7 , following the recommendations of Hair Jr. et al. (2005).

We processed the data by factor analysis using the SPSS program, which helps validate the sample, in its degrees of reliability, apart from deviations from the standard behavior of variables. For Hair Jr. et al. (1998), factor analysis is a technique whose main goal is to define a structure of variables underlying the data set actually observed. It helps explain the correlation or covariance between a set of variables and facilitates the condensation of the information originally provided by a large number of variables into a smaller set. It is a technique of interdependence and there is no explicit dependent variable. In the present case, we applied a type of Q-type factor analysis, which allows condensing a large number of observations into different groups (clusters).

\section{DATA ANALYSIS}

The participating companies operate in different segments, with no concentration in any of them. Of the 26 companies identified, 13 were family firms. Six respondents mentioned having stock participation in the companies surveyed, in the range of $15 \%$ to $68 \%$. Among other characteristics of the firms and the respondents, the following are worth highlighting. First, there was is good distribution of age of companies, ranging 6 to 107 years of activity, with the highest concentration in the range between 30 and 39 years. Also in relation to the time of action of the respondent in the company, there was a good distribution, ranging from 1 year to 35 years, with the highest concentration of up to 15 years.

The number of employees identified in the surveyed companies ranged from 128 employees in the smallest company to 40,000 in the largest, and $65 \%$ had up to 1,000 employees. Medium-sized companies represented $43 \%$ and large ones $57 \%$. In relation to the respondents' profile, $31 \%$ were in low or mid-level management positions and the remaining $69 \%$ were senior managers, showing good knowledge of the strategic issues in the companies. Concerning training, the vast majority (19 out of 26 ) had graduate study.

\subsection{IDENTIFICATION OF STRATEGY}

The statistical analysis of the issues related to the identification of strategy as well as the companies' performance was developed from the 72 initial items of the questionnaire, starting by factor analysis to identify clusters of these factors. The first factor analysis performed received an explanation of $92 \%$, with 19 factors, a high number for more effective reflection. Further analysis was performed with ten factors, which explained $72 \%$ of the variance, which was accepted. After reading the questions within the primary clusters formed, the final 
clusters were defined according to factor loading in first place or the degree of relationship to other variables in the cluster. Values were calculated for Cronbach's alpha, which is a measure for quantifying the degree of internal consistency of scales. According to Hair Jr. et al. (1998, p. 88), values above 0.6-0.7 are acceptable. In general, all values of Cronbach's alpha were above the acceptable threshold. Only factor 8 showed coefficient of 0.57 , close to the limit of Hair Jr. et al. (1998) and therefore is not considered in this analysis.

Table 3 - Degree of Agreement with the Factors of Factor Analysis for f1, f2, f3, f5, f6, f7, f9 and f10.

\begin{tabular}{|l|l|l|}
\hline Averages between & Colors & Agreement \\
\hline 1 to 1.9 & None & Very low or nonexistent \\
\hline 2 to 2.9 & Red & Low \\
\hline 3 to 3.9 & Yellow & Average \\
\hline $4-5$ & Green & High \\
\hline
\end{tabular}

The factors are f1 - Competency and Quality, f2 - Perception of competency, f3 Typology - Prospector f4 - Transfer of Skills, f5 - Focus on distribution/marketing, f6 Performance, f7 - Product Technology, 88 - Mission - Disinvest, f9 - Differentiation and f10 Price and area of activity. After factorial analysis, we grouped the responses in order to identify behavior profiles. The technique used was analysis of Clustering k-means .To facilitate analysis, we used colors to differentiate the degree of agreement (Table 1). These colors follow the line of a traffic light, which helps in understanding and visualization of models, as demonstrated later in this work.

The means should be analyzed according to the same scale of agreement, from 1 to 5 , where 1 is low and 5 is full agreement. These levels of agreement fit perfectly for the factors f1, f2, f3, f5, f6, f7, f9 and f10. However, some caveats should be mentioned.

With regard to the factor $\mathrm{f3}$ - Typology, all issues involving the identification of strategic typology are intended for the identification by the degree of agreement with the Prospector group. The opposite of this, that is, to disagree with Prospector, indicates a Defender strategic typology and medium for the Analyst, according to Miles et al. (1978). The agreement levels proposed in Table 2 identify the Prospector and, to the extent that they move away, they suggest an approximation to the other groups, identified as Analyst for medium concordance and Defender for low concordance.

The same applies to the strategic mission represented by factor f8. The level of agreement proposed in Table 4 identifies companies with characteristics of Harvest, and to the 
extent that they move away, it suggests approximation to other groups, identified as Hold for medium concordance and Build for the low concordance.

The level of agreement of the $\mathrm{f} 4$ - Transfer of Competencies evaluates the level of internal mobility of competencies of the companies, i.e., the higher the correlation, the lower the ability of companies to retain such skills. Therefore, the lower the correlation with the ability to transfer skills to other companies, the better the benefit received by the company that has this competency. Thus, the range of validation for this group takes place in the reverse order to that presented in Table 3.

Table 4 - Mean of Agreement of the Associated Factors with the Formed Clusters and their Rankings

\begin{tabular}{|c|c|c|c|c|c|c|c|}
\hline & \multirow[b]{2}{*}{ FACTORS } & \multicolumn{6}{|c|}{ CLUSTERS } \\
\hline & & 1 & 2 & 3 & 4 & 5 & 6 \\
\hline f1 & Competency and quality & 3.1 & 4.7 & 4.5 & 4.2 & 4 & 4.3 \\
\hline $\mathrm{f} 2$ & Perception of competency & 2.8 & 3.9 & 3.9 & 3.9 & 3.2. & 3.4 \\
\hline f3 & Typology - Prospector & & 4.4 & 4.2 & 4.1 & & 4.2 \\
\hline f3 & Typology - Analyst & 3.4 & & & & 3.6 & \\
\hline f3 & Typology - Defender & & & & & & \\
\hline f4 & Transfer of competencies & 2.9 & 2.1 & 3 & 2.9 & 2.6 & 1.7 \\
\hline f5 & Focus on the distribution/marketing & 3.7 & 4.3 & 3.4 & 3.6 & 3.3 & 2.9 \\
\hline f6 & Performance & 2.3 & 4.5 & 3.9 & 3.5 & 3.2 . & 3.9 \\
\hline $\mathrm{f} 7$ & Product technology & 4.1 & 4.5 & 4.5 & 3.9 & 3.9 & 4.5 \\
\hline f8 & Mission - Hold & 3.3 & 3.6 & & & & \\
\hline f8 & Mission - Harvest & & & & 4.1 & & \\
\hline f8 & Mission - Build & & & 2.3 & & 2.8 & 2.7 \\
\hline f9 & Differentiation & 2.9 & 4.3 & 4.5 & 4.2 & 4.2 & 3.2 . \\
\hline $\mathrm{f} 10$ & Price and area of operation & 2.3 & 3.4 & 3.9 & 4.2 & 2.7 & 3.8 \\
\hline
\end{tabular}

It is important to note that when conducting the framework of the factors $\mathrm{f} 3$ and $\mathrm{f} 8$, the sense of high, medium or low agreement highlighted above did not apply. So, after establishing their rank within their factors, we adopted the approach as appropriate for the described situation. However, we were unable to identify through factorial analysis of the sample the characteristics to demonstrate the competencies related to the quest for cost leadership in accordance with the model proposed by Grant (1991). We now assess each cluster individually. 


\subsubsection{Analysis of Cluster 1}

The characteristics listed in Cluster 1 are: a high correlation to issues associated with Product technology and the Transfer of competencies; the strategic typology is consistent with Analyst, while the mission is related to Hold; partial to medium agreement on issues related to the factors Focus on distribution/market and Competency and quality; and low agreement on issues relating to Price and area of operation, Performance, Perception of competency and Differentiation. These characteristics are correlated with the integration model of the strategy proposed by Kald, Nilsson \& Rapp (2000) and they can be viewed in Figure 2. It appears that the Typology has a connection with the strategic Mission, however issues related to cost leadership and differentiation have low agreement by companies participating in the cluster, i.e., the strategies of companies that make up this cluster cannot be explained by the strategic positioning approach.

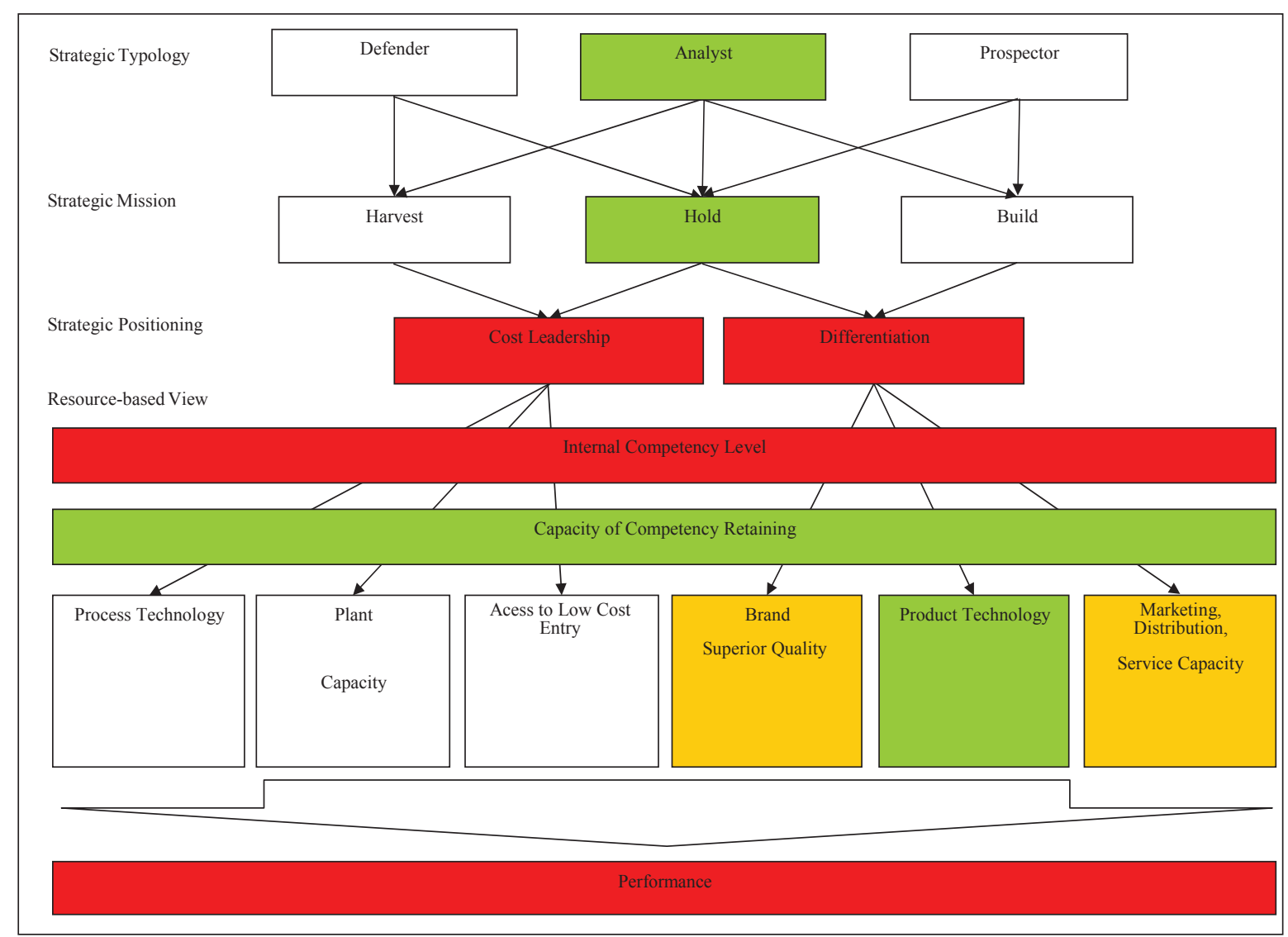

Figure 2 - Strategic approaches to Cluster 1

Another issue that is observed is the low level of competency of these companies. Because they have little agreement with the features that constitute competency, the ability to retain their competencies is high, perhaps even by the low interest of competitors in wanting to acquire those competencies, which those same companies consider low. 


\subsubsection{Analysis of Cluster 2}

The characteristics displayed by the second cluster can be described as: high agreement for questions related to Competency and quality, Product technology, Performance, Typology - Prospector, Differentiation, Focus on the distribution/marketing, Transfer of competencies and Mission - Hold; and partial to medium agreement on issues related to the factors Perception of competency, Mission and Price and area of operation. There are no factors with low agreement. Figure 3 shows the relationship with the strategic integration model. It can be seen that the strategic approaches have an explanation supported by the model of Kald, Nilsson \& Rapp (2000). Another aspect in this figure is that, even though seeking differentiation, firms are not neglecting aspects related to costs (PORTER, 1989).

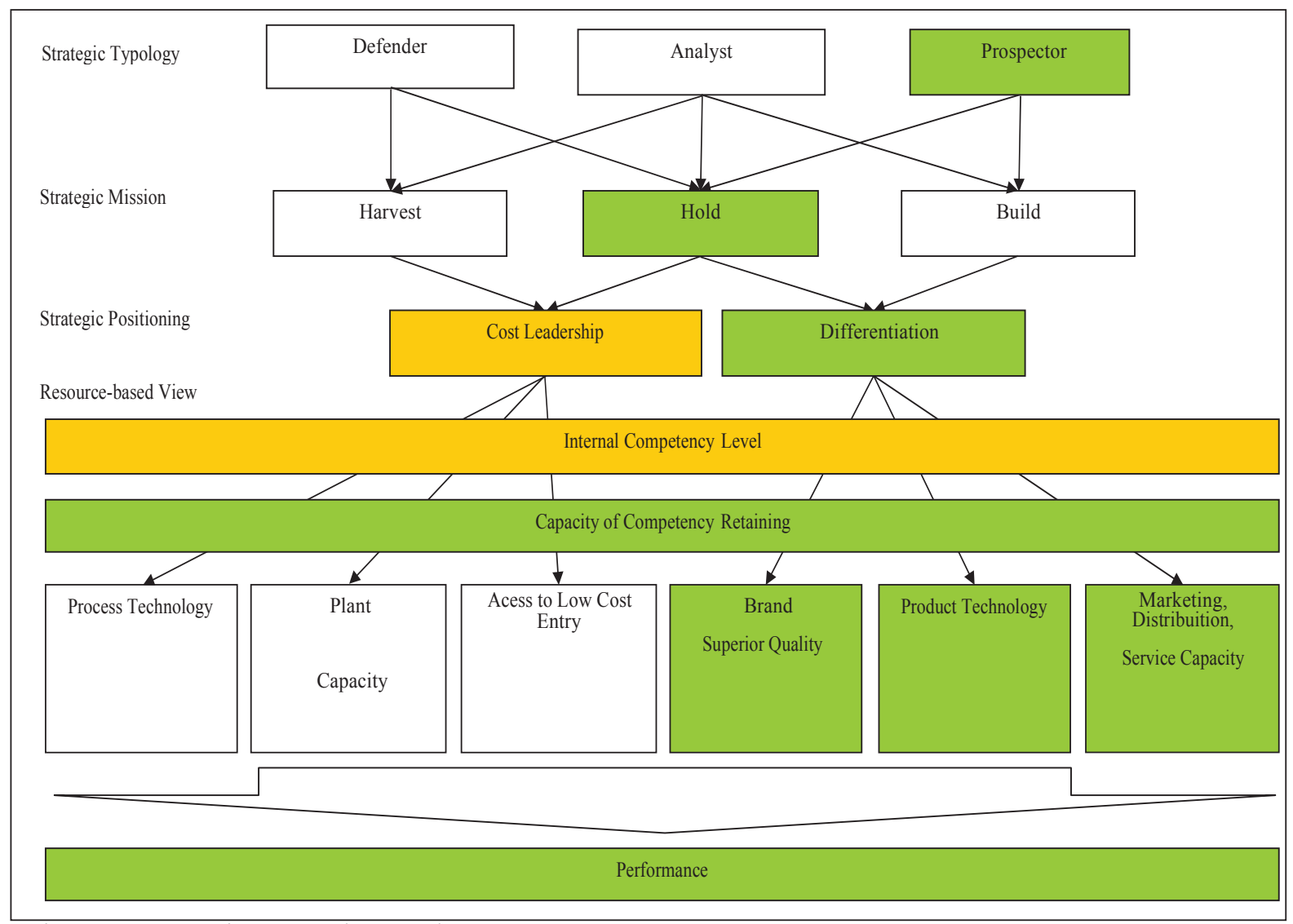

Figure 3 - Strategic approaches to Cluster 2

Another aspect of this cluster is that the level of recognized competency is not high, though the companies that comprise it seem to pay attention to the issue of mobility of those competencies, as it is with low intensity. The results show that this integration leads to good performance. 


\subsubsection{Analysis of Cluster 3}

Figure 4 shows the relationship of cluster 3 with the strategic integration model. The characteristics of this cluster are: high agreement with the questions related to Competency and quality, Product Technology, Differentiation, Typology - Prospector and Mission - Build; and partial to medium agreement on issues related to the factors Perception of competency, Performance, Price and area of operation, Focus on distribution/marketing and Transfer of Competencies. No factor has a low correlation.

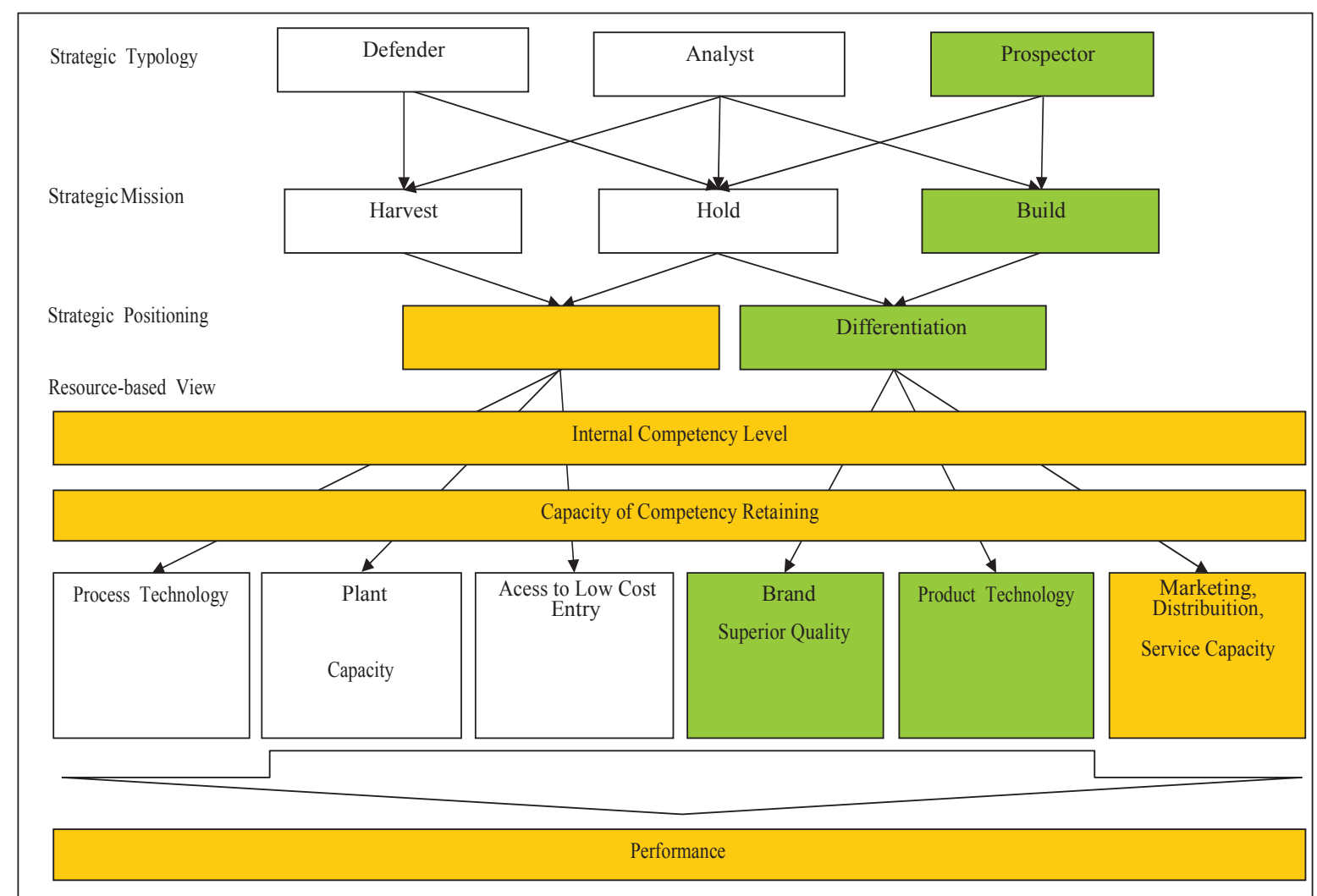

Figure 4 Strategic approaches to Cluster 3

It can be observed that all the strategic approaches have a pattern explained by the model. As in cluster 2, the aspects related to costs are not being overlooked, even when there is a search for differentiation. On the other hand, aspects related to Marketing, distribution and service capacity appear with less intensity in this cluster.

The level of competency of this cluster is considered medium at the same levels of cluster 2. However, companies of cluster 3 have medium degrees of mobility of those competencies. This medium mobility of competencies seems to be a major reason why the perceived performance was medium. 


\subsubsection{Analysis of Cluster 4}

Figure 5 shows the relationship with the strategic integration model of this cluster. The characteristics displayed by Cluster 4 can be described as: high agreement for questions related to Competency and quality, Differentiation, Price and area of operation, Transfer of competencies, Typology - Prospector and Mission - Harvest; and partial to medium agreement on issues related to the factors Perception competency, Product technology, Focus on the distribution/marketing and Performance. Again, there is no factor with low correlation.

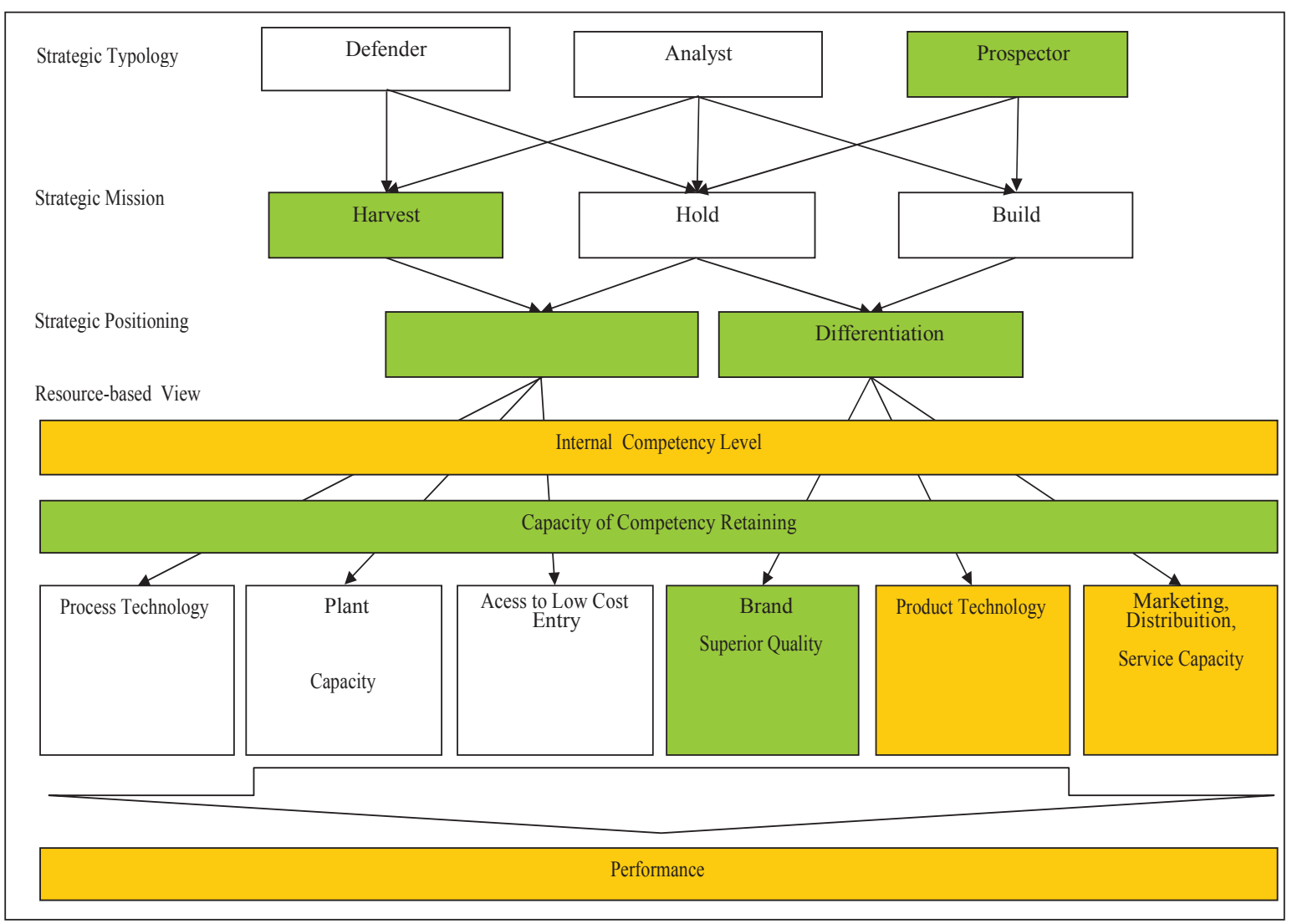

Figure 5 Strategic approaches to Cluster 4

In Figure 5, there is no link between the strategic approaches of the typology and mission, while this cluster obtains high level of agreement with differentiation and in the pursuit of cost leadership for strategic positioning. These features cause the company not to achieve optimal results - above the market average performance. As Porter (1989) emphasized, this kind of attitude is a recipe for mediocrity, a result that can be recognized for companies that make up this cluster.

The aspects related to the product technology and of market (Marketing, distribution and service) do not have the same attention to the Brand and Superior Quality, causing the aspects of differentiation to decline in importance. 


\subsubsection{Analysis of Cluster 5}

The characteristics of cluster 5 are high agreement to the questions related to Differentiation, Competency and quality, Typology - Analyst, Mission - Build, and Transfer of competencies, partial to medium agreement on issues related to the factors Product technology, Focus on the distribution/marketing, Perception of competency and Performance; and low agreement on issues relating to Price and area of operation.

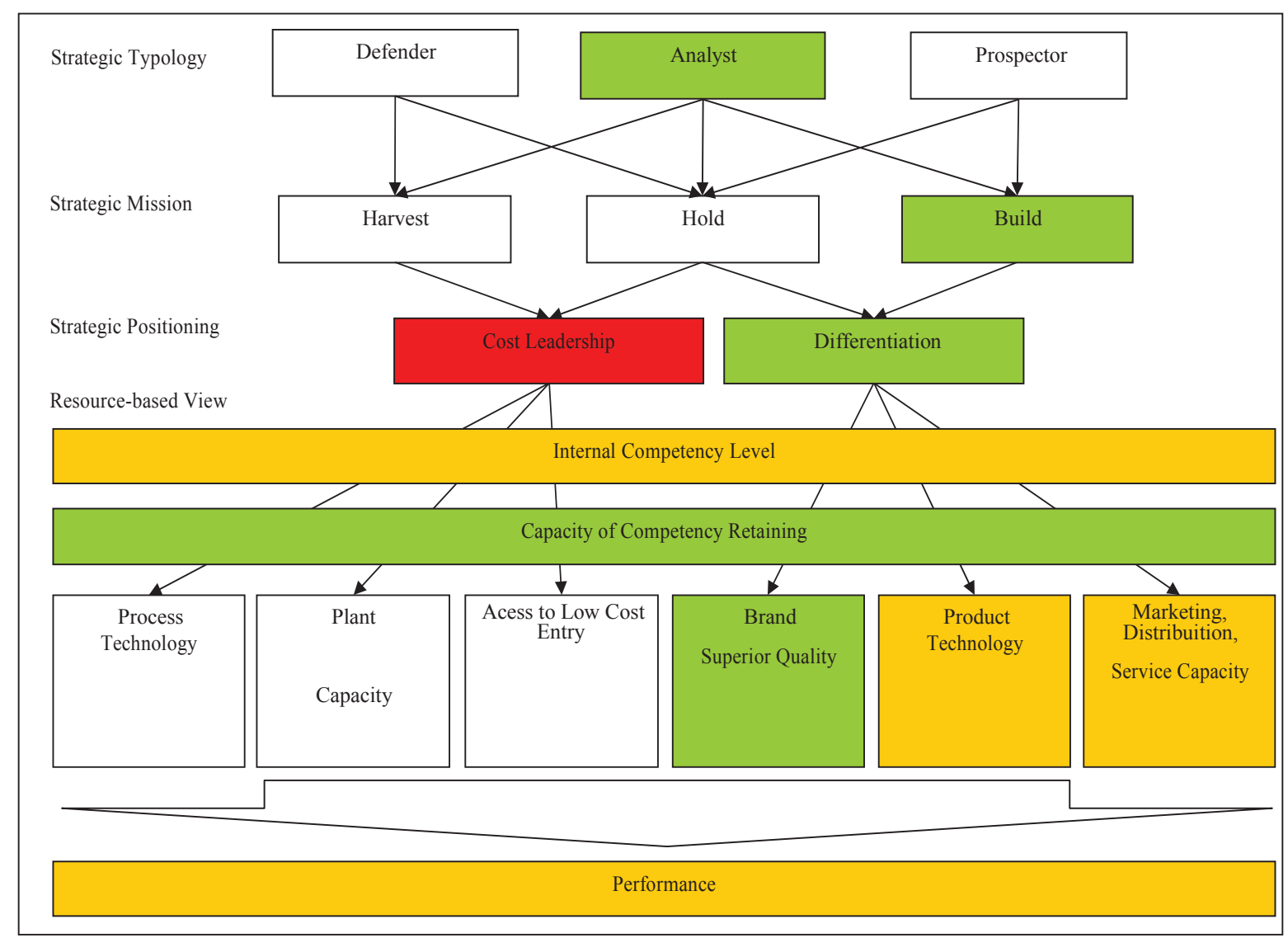

Figure 6 - Strategic approaches to Cluster 5

Figure 6 describes the relationship with the strategic integration model. With similar characteristics to cluster 4, relating to the Level of Competency, Retention Capacity and resources, cluster 5 uses the link between the strategic approaches of Typology, Mission and Positioning, which has a foreseen link to the theory as viable. Yet by failing to exercise control over their costs, the firms in this cluster are not able to obtain superior performance based only on differentiation.

\subsubsection{Analysis Of Cluster 6}

The characteristics shown by cluster 6 can be described as: high agreement for issues related to Product technology, Competency and quality, Typology - Prospector, Mission Build and Transfer of competencies; partial to medium agreement for the issues related to the 
factors Performance, Price and area of operation, Perception of competency and Differentiation; and low agreement on issues related to Focus on distribution/marketing.

Figure 7 shows the relationship with the strategic integration model. For cluster 6, with a typology of Prospector, and mission of Build, it is expected that it possesses a strategic position based on differentiation, and this does not occur in the intensity that it should occur. The level of agreement with the differentiation is medium and firms search for cost leadership with the same intensity, a combination that does not generate competitive advantage. Regarding RBV, although the level of competency is medium, there is good ability to retain such competencies based on Brand, superior quality and Product technology. On the other hand, there is denial of the issues related to Marketing, distribution and service capacity.

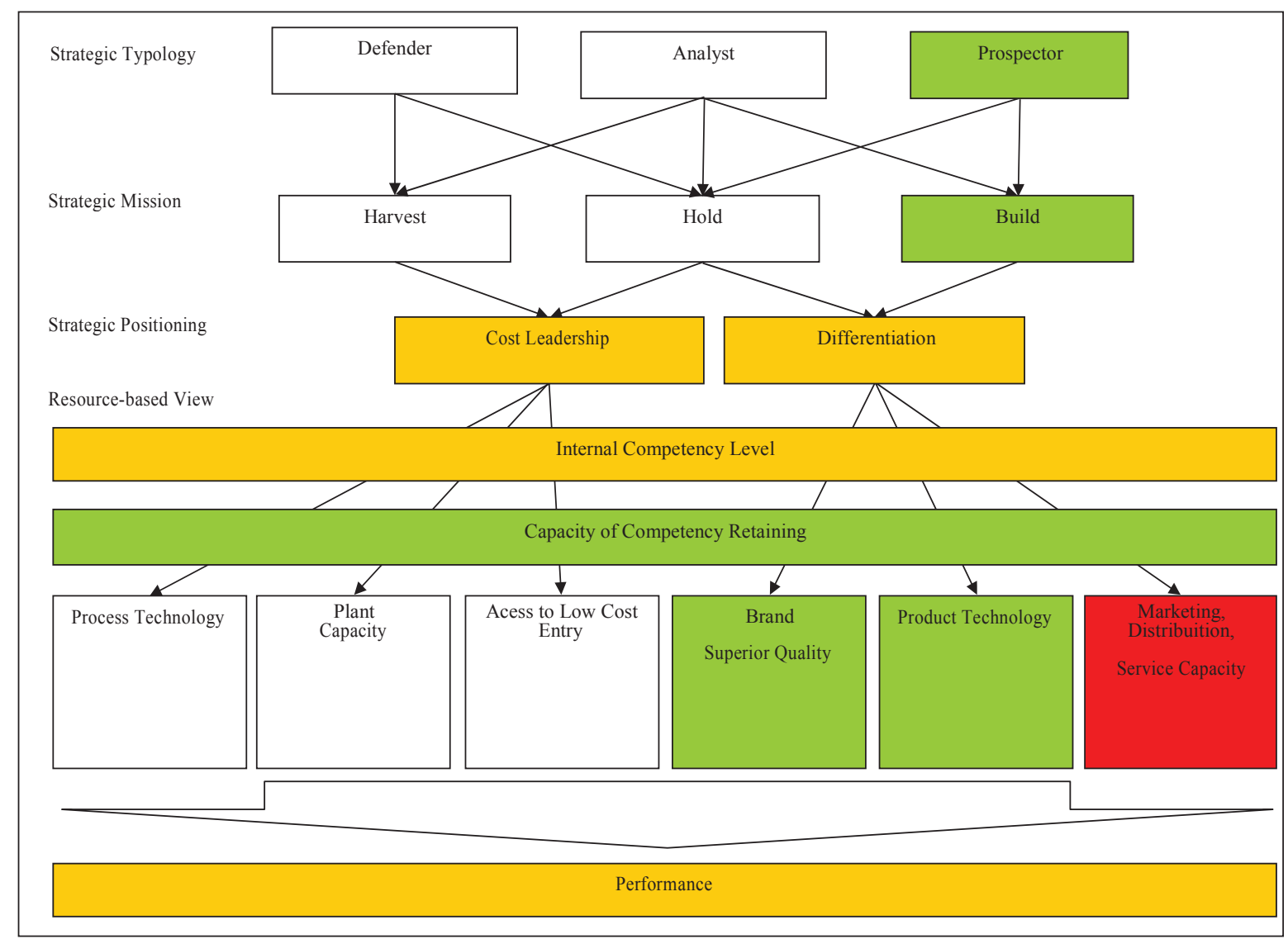

Figure 7 - Strategic approaches to Cluster 6

We also cross-referenced the characteristics of the companies comprising the sample with the groups formed by cluster analysis with the purpose of identifying characteristics that could evaluate the clusters based on these characteristics. However, it was not possible to identify any pattern of behavior in relation to issues of profile of the respondents and the companies with the formed clusters. 


\section{CONCLUSION}

The interrelationships of a firm with its environment require constant adjustments to their way of acting, with a single purpose: to gain a competitive advantage that enables performance better than the average of the other companies in its segment (PORTER, 1989). This study aimed to identify the organizational strategies associated with them of a group of 32 medium and large companies in southern Brazil. This was possible by examining each of the strategic approaches within each of the six clusters identified with the aid of the factor analysis technique. However, we did not only focus on this aspect. Our aim was to establish a link between the strategic approaches adopted by these clusters with the performance perceived by them.

Because of the strategic choices and the perceived performance by managers, we can say that cluster 2 shows high performance because it presents the best link between the strategic approaches. Cluster 3 also shows good connection between the strategic approaches, but it has low retention of competencies and thus its performance drops to the market average. Similar to cluster 3, cluster 6 shows a good capacity to retain internal competencies, but does not seek specific strategic positioning for differentiation, the only viable option considering the other strategic choices.

Cluster 4 , in contrast to cluster 6 , seeks strategic position of cost leadership and differentiation simultaneously, which leads to a medium performance position. A company with a Prospector typology should not have a strategic mission of Harvest, because these choices are not compatible, which explains the medium performance. Cluster 5 presents a good setting of its strategic approaches, however, when choosing differentiation it disagrees substantially with the issues related to cost. Porter (1989) stated there must be strict control of costs in the areas not related to differentiation and this cluster does not seem to stick to it. Finally, with below-average performance, cluster 1 ignores the search for differentiation or cost, and also has a low level of competency. The potential value of resources depends on interaction among them and betweent them and organizational configuration (CARVALHO; PREVOT; MACHADO, 2012).

It can be said that the more strategic choices are aligned with the theoretical model the better the performance achieved by the companies in this sample. With the application of this instrument, it is possible to show more clearly the strategic choices of organizations and more easily demonstrate their relationship with management control. Moreover, it is possible to perform comparative analysis among studies that based on different schools or strategic 
approaches. It seems necessary to use more than one variable to evaluate relationships between strategy and competitiveness, mainly in small companies (FREITAS, 2012). This proposal is also advocated by Canhada \& Bulgacov (2011), who stated it is necessary investigate which behavior standards are related with outcomes types. Our study followed this approach using performance perception, a broader view of outcomes.

Therefore, the results seem to corroborate Newbert (2008), for whom resources are determinants of performance. Furthermore, the reinforcement between Porter's value chain and RBV's capacities is expected by Ito (2011). Also, although this study does not apply an extended case method, it helps to integrate existing theories (ALBINO et al., 2010) by showing the alignment among some strategy`s schools and their agreement with performance perception in the firms studied.

A way to explain the alignment among different practices in the studied companies is isomorphism. For Walter, Augusto \& Silva (2011), organizational agents can adapt institutional practices to their organization, resulting in a type of mimesis. Nevertheless, in this case a new way is necessary to explain their common perception of successful performance.

Another explanation for the alignment among different practices is equifinality (MACIEL; WEYMER; AUGUSTO, 2012). In this sense, different actions are taken to respond to the same strategic context.

Another way to explain it is that companies that did not fit well in the proposed model compete in an increasingly competitive business world (ADLER, 2011). In this case, our model perhaps does not describe in precise way all companies, but rather better fits those that compete in a more stable environment. Therefore, this limitation could be a future research opportunity.

Because of the strategic choices of the organization and its alignment or not with the theoretical model, it is possible to establish what information is important to performance evaluation. According to Rocha (1999), this task is part of the controller's function. Professional in this area must have clearness about organizational strategies both to support decision making with the necessary information for making better choices and to actively participate in this process. 
In this sense, from the criteria that involve an information system, planning and control, we recommend further to research of the types of controls used for each strategic approach, which can improve management control of companies.

\section{REFERENCES}

ACQUAAH, M; YASAI-ARDEKANI, M. Does the implementation of a combination competitive strategy yield incremental performance benefits? A new perspective from a transition economy in Sub-Saharan Africa. Journal of Business Research, n. 61, p. 346-354, 2008.

ADLER, R. W. Performance management and organizational strategy: how to design systems that meet the needs of confrontation strategy firms. The British Accounting Review, v. 43, n. 4, p. 251-263, 2011.

ALBINO, J. et al. Estratégia como prática: uma proposta de síntese. Revista Portuguesa e Brasileira de Gestão, v. 9, n. 1-2, p. 1-16, jun. 2010. Disponível em:

$<$ http://www.scielo.oces.mctes.pt/scielo.php?pid=S1645-

$44642010000100002 \&$ script $=$ sci_arttext $>$.

ATES, A. Strategy process in manufacturing SMEs. 2008. Thesis. University of Strathclyde, Glasgow (ESC), 2008.

BAGNOLI, C.; VEDOVATO, M. The impact of knowledge management and strategy configuration coherence on SME performance. Journal of Management and Governance, $\mathrm{v}$. 9, mar. 2012.

BARNEY, J. Firm resources and sustained competitive advantage. Journal of Management, v. $1, \mathrm{n} 17,1991$.

BORINELLI, M. L. Estrutura conceitual básica de controladoria: sistematização à luz da teoria e da práxis. 2006. Tese (Doutorado em Contabilidade) - Programa de Pós-Graduação em Ciências Contábeis, FEA/Universidade de São Paulo, São Paulo, 2006.

CANHADA, D. I. D.; BULGACOV, S. Práticas sociais estratégicas e resultados acadêmicos: o doutorado em administração na USP e na UFRGS. RAP - Revista de Administração

Pública, Rio de Janeiro, v. 45, n. 1, p. 7-32, 2011.

CARVALHO, D. M; PREVOT, F.; MACHADO, J. A. D. O papel dos recursos no desempenho organizacional: o uso da teoria da visão baseada em recursos em propriedades rurais. In: ASSOCIAÇÃO NACIONAL DE PÓS-GRADUAÇÃO E PESQUISA EM ADMINISTRAÇÃO (ENANPAD), 36., 2012, Rio de Janeiro (RJ). Anais... Rio de Janeiro: ANPAD, 2012.

CERTO, S. C.; PETER, J. P. Administração estratégica: planejamento e implantação da estratégia. São Paulo: Makron Books, 1993.

CINQUINI, L.; TENUCCI, A. Strategic management accounting and business strategy: A loose coupling? Journal of Accounting \& Organizational Change, v. 6, n. 2, pp. 228-259, 2010 . 
DIEHL, C. A. Gestão estratégica de custos: uma estrutura para análise da estratégia praticada em empresas de serviços. In: CONGRESSO INTERNACIONAL DE CUSTOS, 9., 2005, Florianópolis (SC). Anais... Florianópolis: ANPAD, 2005.

FREITAS, C. A; HOFFMANN, A. Percepção das estratégias de influências dos stakeholders e sua relação com a estratégia genérica: estudo de caso em pequenas empresas comerciais do litoral norte Catarinense. BBR - Brazilian Business Review, v. 9, n. 2, p. 1-25, apr.-jun. 2012.

GIMENEZ, F. A. P. et al. Estratégias em pequenas empresas: uma aplicação do modelo de Miles e Snow. RAC - Revista de Administração Contemporânea, v. 3, n. 2, may-aug. 1999.

GRANT, R. M. The resource-based theory of competitive advantage: Implications for strategy formulation. California Management Review, Berkeley, v. 33, n. 3, Spring 1991.

Contemporary strategy analysis: concepts, techniques, applications. Cambridge: Blackwell, 1992.

GUNTHER, C. Interaction among firm strategy, board control role, information attributes in association with firm performance. 2012. Thesis. School of Business, Bond University (AUS), 2012.

GUPTA, Anil K.; GOVINDARAJAN. V.Business unit strategy, managerial characteristics, and business unit effectiveness at strategy implementation. Academy of Management Journal (pre-1986), v. 27, n. 1; p. 25-41, mar. 1984.

HAIR JR., J. F. et al. Multivariate data analysis. 5. ed. New Jersey: Prentice Hall, 1998, HOFER, C. W.; SCHENDEL. D. Strategy formulation: analytical concepts. St. Paul: West Publishing, 1978.

ITO, N. C. Conversas e construção teórica na administração estratégica: Porter e VBR em uma teoria do valor das transações da vantagem competitiva. In: ASSOCIAÇÃO NACIONAL DE PÓS-GRADUAÇÃO E PESQUISA EM ADMINISTRAÇÃO (ENANPAD), 35., 2011, Rio de Janeiro (RJ). Anais... Rio de Janeiro: ANPAD, 2011.

JARZABKOWSKI, P.; WHITTINGTON, R. A strategy-as-practice approach to strategy research and education. Journal of Management Inquiry, v. 17, n. 4, p. 282-286, dez. 2008.

JUGDEV, K. Developing and sustaining project management as a strategy asset: a multiple case study using the resource-based view. 2003. Tese. (Doutorado) - University of Calgary, 2003.

KALD, M.; NILSSON, F.; RAPP, B. On strategy and management control: the importance of classifying the strategy of the business. British Journal of Management, v. 11, p. 197-212, 2000 .

LAMBERG, J. et al. Competitive dynamics, strategic consistency, and organizational survival. Strategic Management Journal, n. 30, p. 45-60, 2009.

LANGFIELD-SMITH, K. Management control systems and strategy: a critical review. 
Accounting, Organizations and Society, v. 22, n. 2, p. 207-232, 1997.

MACIEL, C. D. O.; WEYMER, A. S. Q.; AUGUSTO, P. O. M. Identificando os condicionantes socialmente construídos (ENACTED) das práticas estratégicas em ambientes altamente institucionalizados. RAC - Revista de Administração Contemporânea, v. 16, n. 1, art.5, pp. 79-97, 2012.

MCDERMOTT, M. A. An empirical investigation of core competence and firm performance. 2003. Tese (Doutorado) - State University of New York at Albany, New York (NY), 2003.

METTS, G. A. An investigation of relationship between strategy making and performance: the role of adaptative decision making in the development of strategy in small and medium-sized manufacturing companies. 2004. Tese (Doutorado) - University of Toledo, Ohio (EUA), 2004.

MILES, R. E. et al. Organizational strategy, structure, and process. The Academy of Management Review, jul. 1978.

MILES, R. E; SNOW, C. C. Organizational strategy, structure and process. New York: McGraw-Hill, 1978.

MINTZBERG, H; AHLSTRAND, B; LAMPEL, J. Safári de estratégia: um roteiro pela selva do planejamento estratégico. Porto Alegre: Bookman, 2000.

MINTZBERG, H; QUINN, J. B. O processo da estratégia. 3. ed., Porto Alegre: Bookman, 2001 .

NAMUSONGE, M. J. Linking competencies with strategy: the case of small and mediumsized exporting firms in Kenya. 2003. Tese (Doutorado) - University of Illinois at UrbanaChampaign, Illinois (EUA), 2003.

NEWBERT, S.L. Value, rareness, competitive advantage, and performance: a conceptual-level empirical investigation of the resource-based view of the firm. Strategic Management

Journal, n. 29, p. 745-768, 2008.

OLIVEIRA, L. M. et al. Gestão estratégica da logística e seus fatores críticos de sucesso. In: CONGRESSO BRASILEIRO DE CUSTOS, 10., 2003, Guarapari (ES). Anais... Guarapari: ABC, 2003.

PORTER, M. E. Vantagem competitiva: criando e sustentando um desempenho superior. Rio de Janeiro, Campus, 1989.

Estratégia competitiva: técnicas para análise de indústrias e da concorrência. Rio de Janeiro: Campus, 2004.

PRZYCZYNSKI, A. R.; BITENCOURT, C. C. Resource-based View (RBV): perspectiva empírica, tendências e abrangência em duas décadas. In: ASSOCIAÇÃO NACIONAL DE PÓS-GRADUAÇÃO E PESQUISA EM ADMINISTRAÇÃO (ENANPAD), 35., 2011, Rio de Janeiro (RJ). Anais... Rio de Janeiro: ANPAD, 2011.

RIGONI, E. H.; HOPPEN, N. Instrumentos de mensuração dos tipos estratégicos: uma análise comparativa no contexto do alinhamento estratégico entre negócios e tecnologia da 
informação. ASSOCIAÇÃO NACIONAL DE PÓS-GRADUAÇÃO E PESQUISA EM ADMINISTRAÇÃO (ENANPAD), 35., 2011, Rio de Janeiro (RJ). Anais... Rio de Janeiro: ANPAD, 2011.

ROCHA, W. Contribuição ao estudo de um modelo conceitual de sistema de informação de gestão estratégica. 1999. Tese (Doutorado) - Programa de Pós-Graduação em Ciências Contábeis, FEA/Universidade de São Paulo (USP), São Paulo, 1999.

RODRIGUES FILHO, J. Um estudo da produção acadêmica em administração estratégica no Brasil na terminologia de Habermas. RAE-eletrônica, v. 3, n. 2, jul.-dez. 2004.

SEHNEM, S; LAZZAROTTI, F; BANDEIRA-DE-MELLO, R. Uma análise longitudinal da utilização do paradigma Porteriano no Brasil. BBR - Brazilian Business Review, v. 7, n. 2, , p. 21-39, maio-ago. 2010 .

SINICKAS, A. Improving understanding of strategy. Strategic Communication Management, v. 10, n. 2, p. 12. feb.-mar. 2006.

SIRMON, D. G. et al. The dynamic interplay of capability strengths and weaknesses: investigating the bases of temporary competitive advantage. Strategic Management Journal, v. 1409, p. 1386-1409, jul. 2010.

SOEKARSONO, T. U. Integration and economics: triangulating on agribusiness competitiveness through strategy and economic theories. 2001. Tese (Doutorado) - University of Illinois at Urbana-Champaign, Illinois (EUA), 2001.

VALADÃO, J. D. A. D.; SILVA, S. S. D. S. E. Justaposições da estratégia como prática e processo de estratégia: antes da visão pós-processual da estratégia. RAM - Revista de Administração Mackenzie, v. 13, n. 2, p. 171-195, apr. 2012.

VIEIRA, V.A. As tipologias, variações e características da pesquisa de marketing. Rev. FAE, Curitiba, v. 5, n. 1, p. 61-70, jan.-apr. 2002.

WALTER, S. A; AUGUSTO, P. O. M.; SILVA, V. O campo organizacional e a adoção de práticas estratégicas: revisitando o modelo de Whittington. Cadernos Ebape. BR, v. 9, jun. 2011, n. 2, p. 282-298, 2011.

WAN, Z. Competitive strategy, competitive forces and business level performance in the U.S.: upholstered, wood household furniture industry. 2004. Dissertação (Mestrado) Mississippi State University, Mississipi (EUA), 2004.

WHIPP, R. Creative deconstruction: strategy and organizations. In: CLEGG, S. R. et al. Handbook of Organization Studies. London: Sage, 1996.

ZEMSKY, P. The timing of resource development and sustainable competitive advantage. Management Science, v. 53, n. 4, p. 651-666, 2007.

ZHUANG, Y. A resource-based view of electronic commerce. 2000. Dissertação (Mestrado) - University at Kentucky, Kentucky (EUA), 2000.

\section{NOTES}

1 SEBRAE is a Brazilian agency for development of small and micro enterprises.

2 The questionnaire is available by requests to $\underline{\mathrm{cd} @ \text { unisinos.br. }}$ 